\title{
Estimating evapotranspiration and groundwater flow from water-table fluctuations for a general wetland scenario
}

\author{
Martha L. Carlson Mazur, ${ }^{1,2 *}$ Michael J. Wiley ${ }^{2}$ and Douglas A. Wilcox ${ }^{3}$ \\ ${ }^{1}$ USGS - Great Lakes Science Center, 1451 Green Road, Ann Arbor, MI USA \\ ${ }^{2}$ School of Natural Resources and Environment, University of Michigan, 440 Church Street, Ann Arbor, MI USA \\ ${ }^{3}$ Department of Environmental Science and Biology, SUNY - College at Brockport, 350 New Campus Drive, Brockport, NY USA
}

\begin{abstract}
The use of diurnal water-table fluctuation methods to calculate evapotranspiration (ET) and groundwater flow is of increasing interest in ecohydrological studies. Most studies of this type, however, have been located in riparian wetlands of semi-arid regions where groundwater levels are consistently below topographic surface elevations and precipitation events are infrequent. Current methodologies preclude application to a wider variety of wetland systems. In this study, we extended a method for estimating sub-daily ET and groundwater flow rates from water-level fluctuations to fit highly dynamic, non-riparian wetland scenarios. Modifications included (1) varying the specific yield to account for periodic flooded conditions and (2) relating empirically derived ET to estimated potential ET for days when precipitation events masked the diurnal signal. To demonstrate the utility of this method, we estimated ET and groundwater fluxes over two growing seasons (2006-2007) in 15 wetlands within a ridge-and-swale wetland complex of the Laurentian Great Lakes under flooded and non-flooded conditions. Mean daily ET rates for the sites ranged from $4.0 \mathrm{~mm} \mathrm{~d}^{-1}$ to $6.6 \mathrm{~mm} \mathrm{~d}^{-1}$. Shallow groundwater discharge rates resulting from evaporative demand ranged from $2.5 \mathrm{~mm} \mathrm{~d}^{-1}$ to $4.3 \mathrm{~mm} \mathrm{~d}^{-1}$. This study helps to expand our understanding of the evapotranspirative demand of plants under various hydrologic and climate conditions. Published 2013. This article is a U.S. Government work and is in the public domain in the USA.
\end{abstract}

KEY WORDS evapotranspiration; Great Lakes; groundwater; water table; wetland

Received 11 November 2011; Revised 11 July 2012; Accepted 8 November 2012

\section{INTRODUCTION}

Estimation of evapotranspiration (ET) and groundwater-flux rate is of fundamental importance in wetland ecohydrological studies (e.g. Williams et al., 2006; Hill and Neary, 2007; Drexler et al., 2008; Sanderson and Cooper, 2008; Nagler et al., 2009). ET represents the principal, and often dominant, mechanism for water loss in many wetland settings (Priban and Ondok, 1985; Wessel and Rouse, 1994; Drexler et al., 2004), and groundwater loading is known to play a key role in structuring certain wetland types (e.g. Boomer and Bedford, 2008; Loheide et al., 2009; van der Kamp and Hayashi, 2009). Understanding plant community responses to climate change requires sound hydrologic data (Burkett et al., 2005), and accurate methods for obtaining estimates of ET losses over the growing season are needed increasingly to understand the implications of climate change for water resource management and adaptation.

Obtaining accurate estimates, however, is particularly difficult in wetlands because of variability in local atmospheric conditions, changing water levels and spatially heterogenous plant community assemblages. Potential (PET) or actual ET (AET) calculated from Penman-type equations utilizing radiation and aerodynamic measurements above the plant canopy (e.g. Penman, 1948; Monteith, 1965; Allen et al., 2005) are often applied in wetland studies, but the resulting estimates are subject to uncertainties in aerodynamic and surface

*Correspondence to: Martha L. Carlson Mazur, Boston College, Devlin 213, 140 Commonwealth Ave., Chestnut Hill, MA, USA. E-mail: martha.carlsonmazur@bc.edu resistance as well as variability in wetland surface characteristics (Drexler et al., 2004). Eddy covariance methods (e.g. Acreman et al., 2003) are particularly accurate but costly to install and maintain (Drexler et al., 2004). Relatively inexpensive and easy to implement, water-level fluctuation (WLF) methods (Lott and Hunt, 2001; Mould et al., 2010) can be useful in wetland situations for estimating AET and groundwater flow because WLFs reflect changes in plant life stage, community composition and antecedent soil moisture conditions that micrometeorological methods do not (Lautz, 2008). These methods utilize diurnal fluctuations in wetland water levels, which reflect direct uptake of groundwater by plants (Loheide et al., 2009). Plants draw down water levels during daylight hours, and groundwater flows continuously, but water-table elevation rebound is most apparent at night, as groundwater flux replenishes the water extracted by ET (Figure 1). The classic work by White (1932) long has been used to estimate groundwater and ET rates empirically in semi-arid riparian areas on a daily scale (e.g. Troxell, 1936; Gatewood et al., 1950; Meyboom, 1967; Gerla, 1992; Laczniak et al., 1999). An added benefit to WLF methods, groundwater flux rates associated with evaporative demand by plants, which are needed in water-balance analyses and wetland hydrogeology studies, can be estimated concurrently with ET from continuous water-level records (Gerla, 1992; Loheide et al., 2005; Butler et al., 2007; Hill and Neary, 2007; Gribovszki et al., 2008; Loheide, 2008). In semi-arid riparian wetlands where water levels are below ground for most of the growing season and precipitation events are infrequent, the 


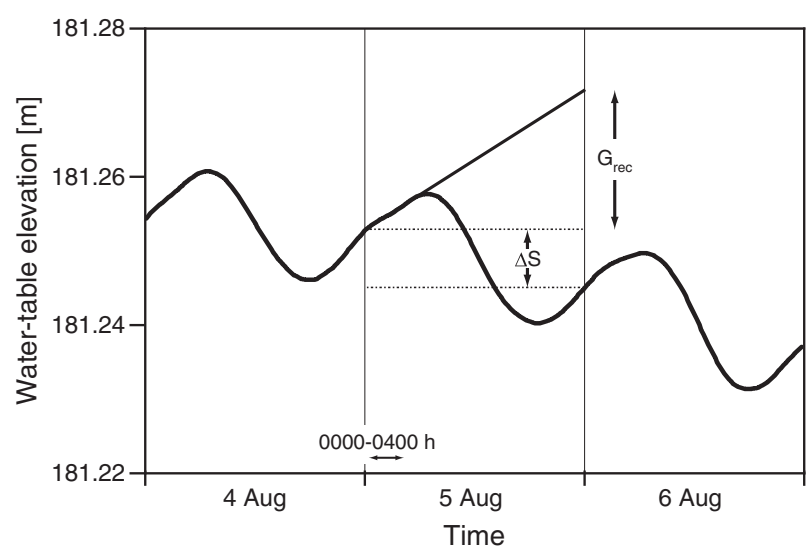

Figure 1. Hydrograph of Swale 55 from 4-6 August 2007 showing the White (1932) method for empirically calculating daily ET. $G_{\text {rec }}$ represents the net groundwater flow over a 24 -h period as extrapolated from the slope of the waterlevel curve from midnight $(0000 \mathrm{~h})$ to $0400 \mathrm{~h}$. Change in storage is depicted by

$\Delta \mathrm{S}$. ET is the sum of $G_{\text {rec }}$ and $\Delta \mathrm{S}$ multiplied by the specific yield, $S_{\mathrm{y}}$.

regular step-down pattern in the water table allows for systematic calculation of ET and groundwater flow.

Application to a more general wetland scenario that includes non-riparian, flooded wetlands, however, is needed. The primary limitations to the WLF method include an inability to apply the method during rain events, under flooded conditions or when water levels drop below the rooting zone (Mould et al., 2010). An additional complicating factor influencing the accuracy of ET estimation by traditional WLF methods involves the inherent assumption that groundwater recovery rate is constant even though we know that it changes over the course of the day with evapotranspirative demand (Troxell, 1936). More recently, researchers have begun examining high-resolution wetland hydrographs on a sub-daily basis to understand nutrient cycling (Schilling, 2007; Schilling and Kiniry, 2007), groundwater consumption (Loheide, 2008) and ET effects on river baseflow (Gribovszki et al., 2008). Gribovszki et al. (2008) and Loheide (2008) extended White's (1932) concept to resolve the recovery-rate problem by calculating ET as a function of time, which increases the accuracy of the ET estimate by addressing variability in groundwater recovery rates. Because of the aforementioned limitations, a sub-daily approach and a combination of PET and WLF methods may be useful.

In this study, we asked: can WLF methods be applied to a more general wetland scenario where flooded conditions and rain events are prevalent? Using both WLF and PET estimates, we developed modifications to the sub-daily method of Loheide (2008) that extend its utility to a wide variety of wetland systems. Applying the method to sub-daily hydrographs from a structurally and vegetatively complex ridge-andswale wetland system in the Great Lakes region, we were able to estimate ET and shallow groundwater fluxes over two annual growing seasons for 15 swales in the wetland system.

\section{METHODS}

\section{Water-level fluctuation theory}

Water-level fluctuation methods allow for the concurrent calculation of groundwater inflow and ET rates. In the sub-daily WLF methods that account for changes in groundwater rates over the course of the day (Gribovszki et al., 2008; Loheide, 2008), groundwater inflow rate, $G_{\text {rec }}\left(\mathrm{mm} \mathrm{h}^{-1}\right)$, is calculated during times of negligible ET as follows:

$$
G_{\text {rec }}=S_{\mathrm{y}}(d h / d t)
$$

where $S_{\mathrm{y}}$ is the readily available specific yield (sensu Meyboom, 1967), and $d h / d t$ represents the change in watertable elevation, h (mm), over time, $t$ (h). The Loheide (2008) method assumes that a groundwater recovery source, located an arbitrary distance away, supplies water to the unconfined aquifer at the observation well. The methodology is summarized here, but the reader is referred to Loheide (2008) for further details. The rate of change in head at the recovery source is assumed equal to the overall water-table rate of change at the well. If this assumption is accurate, the net inflow rate, $G_{\text {rec }}\left(\mathrm{mm} \mathrm{h}^{-1}\right)$, can be estimated by detrending the water-level curve by subtracting the trend slope and intercept from the linear regression of the water-table trend for each day. The detrended water-level curve is then regressed against the rate of change in detrended watertable elevation for the pre-dawn hours of two consecutive nights. The regression is extended to predict the rate of change in detrended water-table elevation over the day, which is retrended and multiplied by specific yield to obtain the hourly inflow rate, $G_{\text {rec }}$. Once the inflow rate is known, $\mathrm{ET}, \mathrm{ET}_{\mathrm{G}}\left(\mathrm{mm} \mathrm{h}^{-1}\right)$, is calculated as follows:

$$
\mathrm{ET}_{\mathrm{G}}=G_{\mathrm{rec}}-\mathrm{S}_{\mathrm{y}}(d h / d t)
$$

For application to a more general wetland scenario (e.g. seasonally flooded flow-through wetlands in humid climates), we used sub-daily methods for calculating ET and groundwater recovery rates while applying several modifications. First, we accounted for perennial flooding using a weighted specificyield correction. Second, we used micrometeorological methods (e.g. Penman-Monteith) in regression analyses to predict $\mathrm{ET}_{\mathrm{G}}$ when precipitation events precluded the use of hydrologic methods. Finally, we allowed a flexible window (from midnight to a time between $0400 \mathrm{~h}$ and $0600 \mathrm{~h}$ ) for defining the pre-dawn hours when ET is assumed to be negligible to ensure the method was more likely to succeed for any given day.

\section{Correcting for above-ground storage}

When a wetland site is flooded, water-table head elevation shows a reduced response per unit change in storage even though the volumetric change is the same. This must occur because the above-ground void volume must equal the storage volume. For perennially flooded wetland scenarios, we adjusted the specific yield $\left(S_{\mathrm{y}}\right)$ for each time step to resolve the discrepancy between flooded and non-flooded conditions. Whereas the readily available specific yield $\left(0<S_{\mathrm{y}}<1\right)$ is appropriate when working with belowground-surface (BGS) water levels (Loheide et al., 2005), a specific yield of 1.0 instead is used for the portion of water that is above-ground surface (AGS) (Mitsch and Gosselink, 2000; Hill and Neary, 2007). This means that under flooded conditions, all standing water will drain under the force of 
gravity. Similar to the composite specific yield of Hill and Neary (2007), we used a weighted specific yield $\left(S_{\mathrm{yc}}\right)$ value to account for the respective portions of the water column that are AGS and BGS. Whereas they assessed actual wetland geometry, we used a rectangular wetland geometry, which is appropriate if ET and groundwater fluxes are calculated as depths (rather than volumes) across a $1-\mathrm{m}^{2}$ cross section of wetland and the slope of the bottom is minimal in relation to the side slopes (Figure 2A). Adopting a similar specific-yield notation, we then calculated a composite specific yield $\left(S_{\mathrm{yc}}\right)$ by Equation (3).

$$
S_{\mathrm{yc}}=S_{\mathrm{yw}}\left(\frac{D_{\mathrm{w}}}{D_{\mathrm{w}}+D_{\mathrm{s}}}\right)+S_{\mathrm{ys}}\left(\frac{D_{\mathrm{s}}}{D_{\mathrm{w}}+D_{\mathrm{s}}}\right)
$$

where $S_{\mathrm{yw}}$ is the specific yield of standing water of 1.0, $S_{\mathrm{ys}}$ is the specific yield of sediments, $D_{\mathrm{w}}$ is the water depth, $D_{\mathrm{s}}$ is the depth from soil surface to a less permeable surface representing the base of the unconfined aquifer (e.g. bedrock or glacial till) and $D_{\mathrm{w}}+D_{\mathrm{s}}$ is the total depth over which the specific yield is estimated (Figure 2).

By convention, the naming scheme ' $\mathrm{ET}_{\mathrm{G}}$ ' usually refers to direct groundwater withdrawal by phreatophytes. When considering water levels above or near land surface, some of the ET is also due to free-water-surface evaporation. In this paper, we maintain the $\mathrm{ET}_{\mathrm{G}}$ notation to indicate calculation from WLFs even though we recognize implicitly that all ET is not due to direct groundwater withdrawal by plants.

\section{Precipitation events and other decoupling from the recovery source}

The Loheide (2008) method assumes that the head at the groundwater recovery source fluctuates at a similar rate as the water-table head at the well. The practical implication of this is that a regression of rate-of-change in detrended water table against the detrended water-table values in the pre-dawn hours of two sequential days should be significant. Lack of significance, signalling inapplicability of the general method, occurs when fluctuations are erratic or during rain events that cause a rapid water-table rise at the surface but a muted and lagged rise at the recovery source. Therefore, a second modification was needed to estimate $\mathrm{ET}_{\mathrm{G}}$ and $G_{\text {rec }}$ for days when the general method could not be applied; we predicted $\mathrm{ET}_{\mathrm{G}}$ from hourly PET using the Penman-Monteith equation and related it to $G_{\text {rec }}$ on a daily basis.

Hourly $\mathrm{ET}_{\mathrm{G}}$ can be predicted using an appropriate linear or nonlinear regression relating $\mathrm{ET}_{\mathrm{G}}$ to PET. The resulting time series, a composite of estimated $\mathrm{ET}_{\mathrm{G}}$ from WLFs and ET values predicted from PET, is referred to henceforth as $\mathrm{ET}_{\mathrm{C}}$.

The Penman-Monteith equation for hourly reference ET (PET $\left.{ }_{\mathrm{PM}}\right)$ (Monteith, 1965; Shuttleworth, 1993; Souch et al., 1996, 1998; Allen et al., 2006) is

$$
\operatorname{PET}_{\mathrm{PM}}=\frac{1000}{\lambda \rho_{\mathrm{w}}}\left[\frac{\Delta\left(R_{\mathrm{n}}-H_{\mathrm{s}}\right)+\rho_{\mathrm{a}} c_{\mathrm{p}}\left(e_{\mathrm{s}}-e_{\mathrm{a}}\right) / r_{\mathrm{a}}}{\Delta+\gamma\left(1+r_{\mathrm{s}} / r_{\mathrm{a}}\right)}\right]
$$

where $\lambda\left(\mathrm{MJ} \mathrm{kg}^{-1}\right)$ is the latent heat of vapourization, $\rho_{\mathrm{w}}$ is the density of liquid water $\left(\mathrm{kg} \mathrm{m}^{-3}\right), \Delta\left(\mathrm{kPa}^{\circ} \mathrm{C}^{-1}\right)$ is the slope of the saturation vapour pressure curve at air temperature $T_{\mathrm{a}}\left({ }^{\circ} \mathrm{C}\right), \gamma\left(\mathrm{kPa}^{\circ} \mathrm{C}^{-1}\right)$ is the psychometric constant, $R_{\mathrm{n}}\left(\mathrm{MJ} \mathrm{m}^{-2} \mathrm{~h}^{-1}\right)$ is the net radiation, $H_{\mathrm{s}}$ is the soil heat flux $\left(\mathrm{MJ} \mathrm{m}^{-2} \mathrm{~h}^{-1}\right),\left(e_{\mathrm{s}}-e_{\mathrm{a}}\right)$ is the vapour pressure deficit of the air $(\mathrm{kPa}), \rho_{\mathrm{a}}$ is the density of air $\left(\mathrm{kg} \mathrm{m}^{-3}\right), c_{\mathrm{p}}$ is the specific heat of air at constant pressure $\left(\mathrm{MJ} \mathrm{kg}^{-1}{ }^{\circ} \mathrm{C}^{-1}\right)$,
A

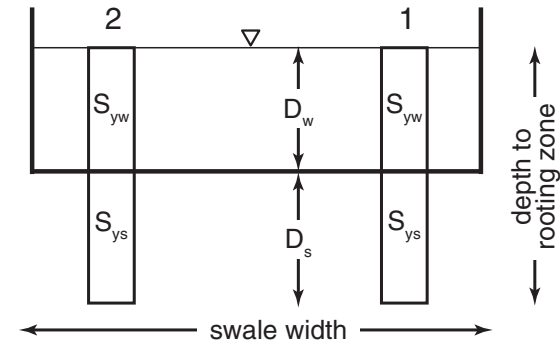

B

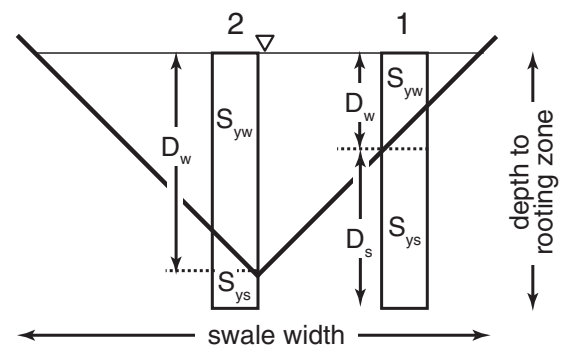

C

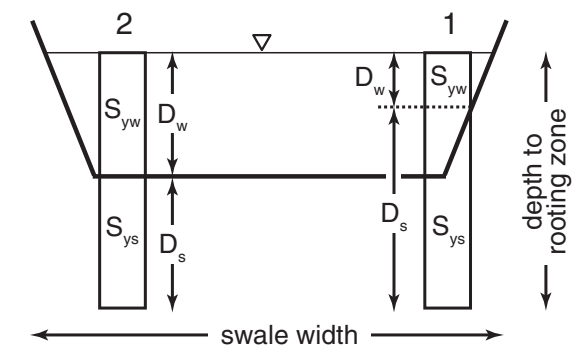

$\mathrm{D}$

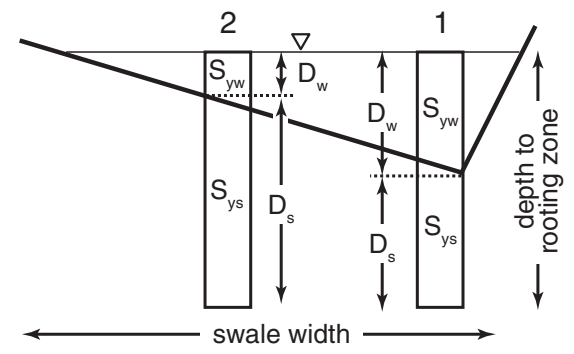

Figure 2. Various wetland geometries in cross section (rectangular, A; conic, B; trapezoidal, C; and oblique conic, D) showing effect of the weighted specific yield ( $S_{\mathrm{yc}}$ ) when the water-level gage is placed at two positions. Position 1 represents the location of the wells in this study, which were installed on the lakeward side of each swale. Position 2 is an alternate location for comparison. The shape of $\mathrm{C}$ is most similar to actual swale geometry (personal observation). $S_{\mathrm{yw}}$ is the specific yield of standing water and is assigned a value of 1.0; $S_{\mathrm{ys}}$ is the soil and sediment specific yield for below-ground water levels. $D_{\mathrm{w}}$ represents the depth of standing water. $D_{\mathrm{s}}$ is the distance from the soil surface to the predepositional surface of the beach-ridge complex. Inverted triangle indicates water surface. Diagrams are not drawn to scale. 
$r_{\mathrm{a}}$ is the aerodynamic resistance $\left(\mathrm{h} \mathrm{m}^{-1}\right)$ and $r_{\mathrm{s}}$ is the surface resistance $\left(\mathrm{h} \mathrm{m}^{-1}\right)$. The value 1000 converts PET units from $\mathrm{mh}^{-1}$ to $\mathrm{mmh}^{-1}$.

We estimated daily groundwater net inflow rate $\left(G_{\text {rec }}\right)$ by linear regression of daily $G_{\mathrm{rec}}$ and daily $\mathrm{ET}_{\mathrm{G}}$ for days when the general method could not be applied. The validity of this relationship is based on the assumption that ET provides a void by which groundwater can flow to the swale, thereby relating ET and groundwater fluxes on a daily scale. We then applied the regression equation for known $\mathrm{ET}_{\mathrm{G}}$ and $G_{\mathrm{rec}}$ values to compute unknown $G_{\text {rec }}$ values from predicted $\mathrm{ET}_{\mathrm{G}}$ values for gaps in the time series resulting from rain events. We then used the composite $\mathrm{ET}_{\mathrm{G}}$ and $G_{\text {rec }}$ data sets, henceforth $\mathrm{ET}_{\mathrm{C}}$ and $\mathrm{G}_{\mathrm{C}}$, containing both directly estimated WLF values and WLF values predicted from PET for subsequent water-balance analyses.

\section{Accounting for daily and seasonal variability}

The time of day when ET is negligible generally is assumed to be from midnight to $0400 \mathrm{~h}$ or $0600 \mathrm{~h}$ (White, 1932; Gerla, 1992; Gribovszki et al., 2008; Loheide, 2008). For the general method to work for a given day, the incremental water-table slopes for corresponding time steps on the night before and the night after must overlap. When applying this method to more variable wetlands, it was necessary to capture the portion of the groundwater inflow curve from midnight to sometime between $0400 \mathrm{~h}$ and $0600 \mathrm{~h}$ when the water-table elevation for that day peaked (Figure 1). Therefore, the pre-dawn hours for each day were defined individually. Doing so accounted for seasonal changes in daylight as well.

In what follows, to illustrate these three modifications (weighting the specific yield, predicting $\mathrm{ET}_{\mathrm{G}}$ from PET and allowing a flexible nighttime window of negligible ET), we apply this method and modifications in a non-riparian wetland system in the Laurentian Great Lakes.

\section{EXAMPLE APPLICATION}

\section{Site description}

A 560-ha, undisturbed ridge-and-swale wetland system consisting of nearly 40 minerotrophic wetlands is located along the west shore of Lake Huron $\left(44.86007^{\circ} \mathrm{N}\right.$, $-83.33288^{\circ} \mathrm{W}$ ) in northeast Michigan, USA, within the boundaries of Negwegon State Park (Figure 3). Over the last 3500 years at this site, coastal processes in an embayment with high sediment supply have led to the preservation of approximately 90 former beach ridges and intervening swales comprising a progradational beach-ridge complex that sits atop a leaky confining layer (T. Thompson, personal communication, 30 May 2005). Sediments are homogeneous fine-to-medium-grained sands with some gravel and very little silt or clay fraction capped by mucky hydric soils in the swales and sandy soils atop ridges (Tawas-Au Gres complex; USDA, NRCS, 2008).

Approximately half of the swales support wetland plant communities varying from sedge meadow or emergent marsh to shrub-scrub or forested wetland. Dominant vegetation types differ among swales but often consist of green and black ash (Fraxinus pennsylvanica Marsh. and Fraxinus nigra Marsh.) in the overstory; the shrubs gray alder [Alnus incana (L.) Moench ] and common winterberry [Ilex verticillata (L.) A. Gray]; and herbaceous vegetation, including sedges (e.g. Northwest Territory sedge, Carex utriculata Boott), bluejoint grass [Calamagrostis canadensis (Michx.) P. Beauv.] and sensitive fern [Onoclea sensibilis L.]. Nomenclature follows the USDA plants database (USDA, NRCS, 2011).

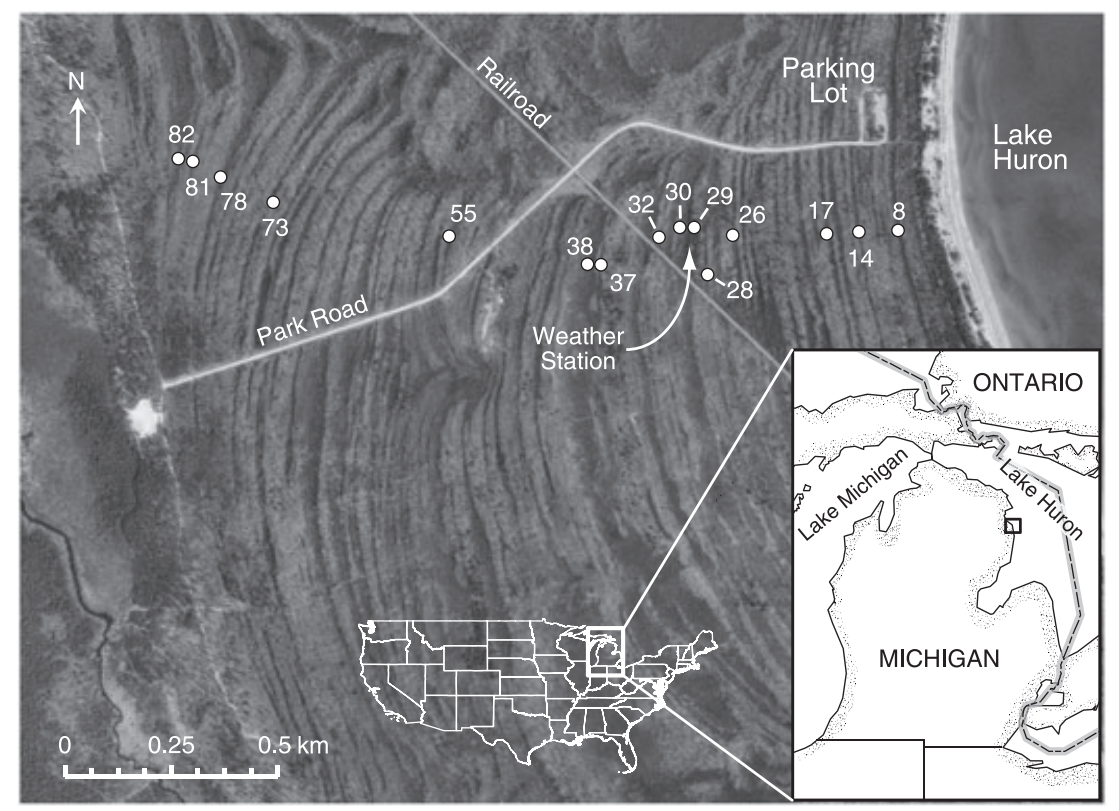

Figure 3. Location (inset) and air photo of the ridge-and-swale system at Negwegon State Park showing the hydrologic sampling sites. The lighter linear features in the photo represent the ridges, and darker features are the swales. 
Characterized by warm summers and cold winters, the climate for most of Lake Huron is described as humid continental in the Köppen-Geiger climate classification (Peel et al., 2007). The 20-year (1987-2007) mean annual precipitation is $721 \mathrm{~mm}$ at the Alpena, MI station $25 \mathrm{~km}$ to the north (NOAA, 2008).

\section{Monitoring wells and sensors}

Fifteen swales were selected for monitoring using a random sample stratified by dominant vegetation class: forested, shrub or herbaceous. In each swale, we installed pressure transducers (Solinst LT Levelogger Model 3001) in slotted wells located on the lakeward side of the swale. We also installed barometric pressure transducers in Swales 29 and 87 (Figure 3). With the exception of the first month of the record in 2006 (ordinal dates 154-183), our barometric pressure sensor was located in a dry well to reduce the thermal effects noted by Cuevas et al. (2010) and McLaughlin and Cohen (2011). To supplement the centrally located weather station (Davis Instruments Cabled Vantage Pro2 Plus), additional sensors in each swale recorded relative humidity and air and soil temperature (Onset HOBO H8 Family). Data were recorded at 5-min intervals ( $15 \mathrm{~min}$ for the weather station) from 20 May to 27 October in 2006 and 14 April to 12 October in 2007.

\section{Sediments}

We collected sand samples from the $\mathrm{C}$ soil horizon of the 15 instrumented wetlands and analysed for texture. Thickness of the beach-ridge complex was determined individually for each swale from core logs collected and described by T. Thompson of the Indiana Geological Survey.

We estimated specific yield $\left(S_{\mathrm{y}}\right)$ as the ratio of infiltrated precipitation to recorded water-table rise (Gerla, 1992). Several researchers have supported the validity of this method in wetlands (Gerla, 1992; Rosenberry and Winter, 1997; Loheide et al., 2005). We approximated $S_{\mathrm{y}}$ for each swale in the study using 2006 and 2007 precipitation events totalling more than $5 \mathrm{~mm}$ per event. Although we recognize implicitly that precipitation that infiltrates to the water table does not include interception by plants and soil, we assumed that infiltrated precipitation equalled recorded precipitation because infiltration was negligible compared with the total precipitation during each storm event greater than $5 \mathrm{~mm}$ per event. Specific-yield values calculated from multiple rain events when the water table was below ground were arithmetically averaged to obtain a single value for each swale (Table I).

\section{Water-level data processing}

Smoothing was required to filter sensor noise from the data that occurred because of the $0.3-\mathrm{cm}$ accuracy of the instrument. Water-level and barometric-pressure data were smoothed using locally weighted, second-order polynomial regression that assigned lower weight to outliers (span $=0.004)$ (Cleveland, 1979; Cleveland et al., 1988). Through an iterative process for testing the optimal smoothing, caution was taken to avoid over-smoothing the data
Table I. Specific yield estimates for the 15 swales.

\begin{tabular}{lcc}
\hline Swale & $S_{\mathrm{y}}(-)$ & Precipitation events \\
\hline 8 & $0.124(0.03)$ & 18 \\
14 & $0.150(0.05)$ & 29 \\
17 & $0.119(0.06)$ & 16 \\
26 & $0.120(0.07)$ & 19 \\
28 & $0.100(0.04)$ & 19 \\
29 & $0.124(0.06)$ & 20 \\
30 & $0.108(0.06)$ & 20 \\
32 & $0.127(0.05)$ & 26 \\
37 & $0.153(0.05)$ & 25 \\
38 & $0.121(0.05)$ & 12 \\
55 & $0.120(0.06)$ & 27 \\
73 & $0.156(0.06)$ & 31 \\
78 & $0.113(0.05)$ & 23 \\
81 & $0.136(0.06)$ & 30 \\
82 & $0.116(0.06)$ & 26
\end{tabular}

Specific yield $\left(S_{\mathrm{y}}\right)$ calculated as the ratio of precipitation to water-table rise was estimated for the number of precipitation events listed for each swale, and the arithmetic mean was used in Equations (2) and (3). Values in parentheses represent standard deviation.

because this can artificially inflate ET and groundwater values by increasing the time base (sensu Snyder, 1938) of the daily fluctuations. Minor gaps in the data $(<0.5 \mathrm{~h})$ occurred when pressure transducers were downloaded; missing values were estimated by spline interpolation prior to smoothing.

We accounted for barometric-pressure effects on the water table and assumed zero barometric efficiency, meaning an instantaneous and direct transmission of barometric pressure on the water table. The results of slope (Ferris et al., 1962) and graphical tests (Gonthier, 2007) supported this assumption, as well as the observation that rain events produced a nearly instantaneous rise in the water table, indicating minimal barometric-pressure lag (T. Rasmussen, personal communication, 18 May 2009). We then used rating curves relating swale water depth to corresponding compensated pressuretransducer data at the time of measurement to convert pressure-transducer data to water depths.

\section{PET parameterization}

Parameterization of the $\mathrm{PET}_{\mathrm{PM}}$ equation (Equation (4)) followed recommended methods in the literature (e.g. Shuttleworth, 1993, Allen et al., 1998), including the air and surface resistance values $\left(r_{\mathrm{a}}, r_{\mathrm{s}}\right)$ given by Souch $e t$ al. (1998) for a similar ridge-swale wetland system. For wind speeds below detection, we assigned a value of half the detection limit of the anemometer $\left(0.22 \mathrm{~m} \mathrm{~s}^{-1}\right)$. We used a daily mean short-wave solar radiation reflection coefficient (albedo, $\alpha$ ) of 0.11, estimated from Shuttleworth (1993) for tall forest. We followed Shuttleworth's (1993) equation for saturation vapour pressure, $e_{\mathrm{s}}(\mathrm{kPa})$. The actual vapour pressure, $e_{\mathrm{a}}(\mathrm{kPa})$, was calculated from the measured relative humidity, $\mathrm{RH}(\%)$, and the saturated vapour pressure, $e_{\mathrm{s}}$ at air temperature $T\left({ }^{\circ} \mathrm{C}\right)$, following Allen et al. (1998). The variables $\lambda, \Delta$ and $\gamma$ were calculated using methods outlined in Shuttleworth (1993). $R_{\mathrm{n}}$ is the difference between incoming net shortwave radiation, $R_{\mathrm{ns}}\left(\mathrm{MJ} \mathrm{m}^{-2} \mathrm{~h}^{-1}\right)$, and outgoing net longwave radiation, $R_{\mathrm{nl}}\left(\mathrm{MJ} \mathrm{m}^{-2} \mathrm{~h}^{-1}\right)$. After 
Allen et al. (1998), we used the following components to calculate $R_{\mathrm{ns}}$ and $R_{\mathrm{nl}}$ : measured incoming shortwave radiation, $R_{\mathrm{S}}\left(\mathrm{MJ} \mathrm{m}^{-2} \mathrm{~h}^{-1}\right)$; their Equation (28) for extraterrestrial radiation, $R_{\mathrm{a}}\left(\mathrm{MJ} \mathrm{m}^{-2} \mathrm{~h}^{-1}\right)$; their Equation (37) for clear-sky solar radiation, $R_{\mathrm{so}}\left(\mathrm{MJ} \mathrm{m}^{2} \mathrm{~h}^{-1}\right.$; and their Equation (39) for $R_{\mathrm{nl}}\left(\mathrm{MJ} \mathrm{m}^{2} \mathrm{~h}^{-1}\right)$. We used the relative solar radiation ratio of actual solar radiation, $R_{\mathrm{s}}$, to $R_{\mathrm{so}}$ that was calculated $2-3 \mathrm{~h}$ prior to sunset to estimate the ratio for nighttime hours (Allen et al., 1998). Equations (45) and (46) of Allen et al. (1998) were used to determine the soil heat flux, $G_{\mathrm{s}}$. We used a value of $0 \mathrm{~s} \mathrm{~m}^{-1}$ for the bulk surface resistance, $r_{\mathrm{s}}$, for standing water levels and $5 \mathrm{~s} \mathrm{~m}^{-1}$ for below-ground water levels, following Souch et al. (1998) for similar ridge-swale wetlands. We used a plant height of $0.12 \mathrm{~m}$ and the standard FAO method for aerodynamic resistance, $r_{\mathrm{a}}$ (Allen et al., 1998).

To relate hourly $\mathrm{ET}_{\mathrm{G}}$ to $\mathrm{PET}$, we used nonlinear regression analysis, which minimized the root-mean-square error (RMSE) better than linear regression. A power function was fit by least squares (Seber and Wild, 2003). Negative and zero values were removed prior to analysis. A theoretical power relationship may exist between AET and PET. As temperature and radiation increase, PET continues to increase. Actual ET, however, may decrease at midday because of photoinhibition, heat stress or water limitation, resulting in an asymptotic relationship between AET and PET. When this is the case, a nonlinear PET-ET ${ }_{G}$ relationship may be more appropriate than a linear one.

\section{Composite ET and groundwater}

We calculated $\mathrm{ET}\left(\mathrm{ET}_{\mathrm{G}}\right)$ and shallow groundwater recovery $\left(G_{\text {rec }}\right)$ at 15-min intervals using the Loheide (2008) method. We used modifications to this method to calculate the composite sub-daily ET $\left(\mathrm{ET}_{\mathrm{C}}\right)$ and daily groundwater $\left(\mathrm{G}_{\mathrm{C}}\right)$ time series as described earlier. Programming was performed in MATLAB R2007a v.7.4 (Mathworks, 2007).

\section{Addressing the rain dilemma}

The days when rain events occur pose a particularly challenging problem for estimating ET. Sensors tend to experience large errors during rainstorms, which affects the accuracy of micrometerological methods. WLF methods are also problematic because of a rapid rise in water-table elevation and subsequent percolation losses. As such, the accuracy of relationships between PET and $\mathrm{ET}_{\mathrm{G}}$ during periods of rain also may be questionable. Many researchers (e.g. Wilson et al., 2001; Mould et al., 2010) have chosen to omit calculations on such days altogether. If annual water budgets are desired, however, estimates for ET on rainy days are important. An alternative is to assume that no ET directly from the water table occurs on days with rain events and that any ET that occurs is a result of evaporation of intercepted rain. Diurnal losses are apparent in the hydrograph following rain events, however, suggesting that a zero ET assumption is also empirically inaccurate. Using single-factor analysis of variance (ANOVA), we compared ET estimates derived from the PET-ET ${ }_{\mathrm{G}}$ relationship and estimates that assume a zero ET value for rainy days to ascertain the potential effects of such uncertainties.

\section{RESULTS}

\section{Water levels}

Because of water extraction by ET, the potential existed for water to flow toward the swale, as evidenced by the time lag between ET and groundwater peaks (Figure 4). Although precipitation events (Figure 5A) offset evapotranspirative losses, water supply to the swales was not sufficient to offset ET demand, resulting in water-level decline over the summer (Figure 5B). The additive effect of groundwater and precipitation, however, helped to maintain water levels within the rooting zone, as evidenced by diurnal fluctuations in the water table even when at its lowest elevation. In 2006, rain events periodically raised the water table. In 2007, standing water levels were maintained until mid-summer by multiple small rain events and colder temperatures; the long period without a major rain event led to a significant drawdown in July and August of 2007 (Figure 5B). Whereas

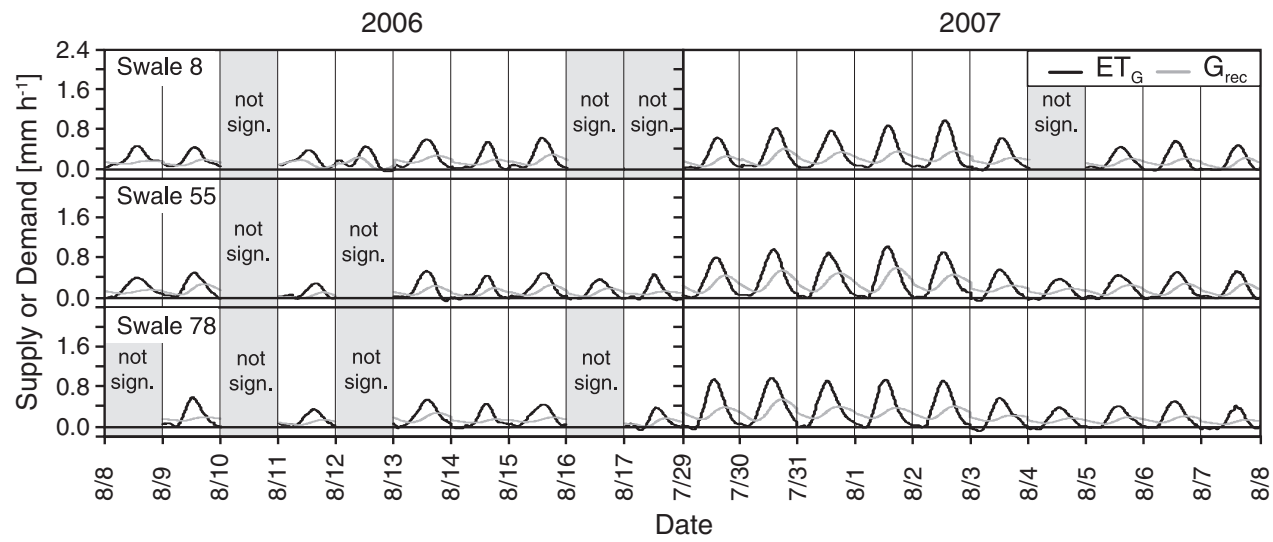

Figure 4. Estimated evapotranspirative demand $\left(\mathrm{ET}_{\mathrm{G}}\right)$ and shallow groundwater recovery $\left(G_{\mathrm{rec}}\right)$, determined from the water-level fluctuation method (Loheide, 2008) and modifications presented in this study, over two 10-day periods (8-18 July 2006 and 29 July to 8 August 2007 ) for a representative three of the 15 swales. A three-to four-hour lag was observed between the respective peaks in rate of ET and groundwater. On some days, test statistics used to evaluate the Loheide (2008) method were not significant, as noted (not sign.). 


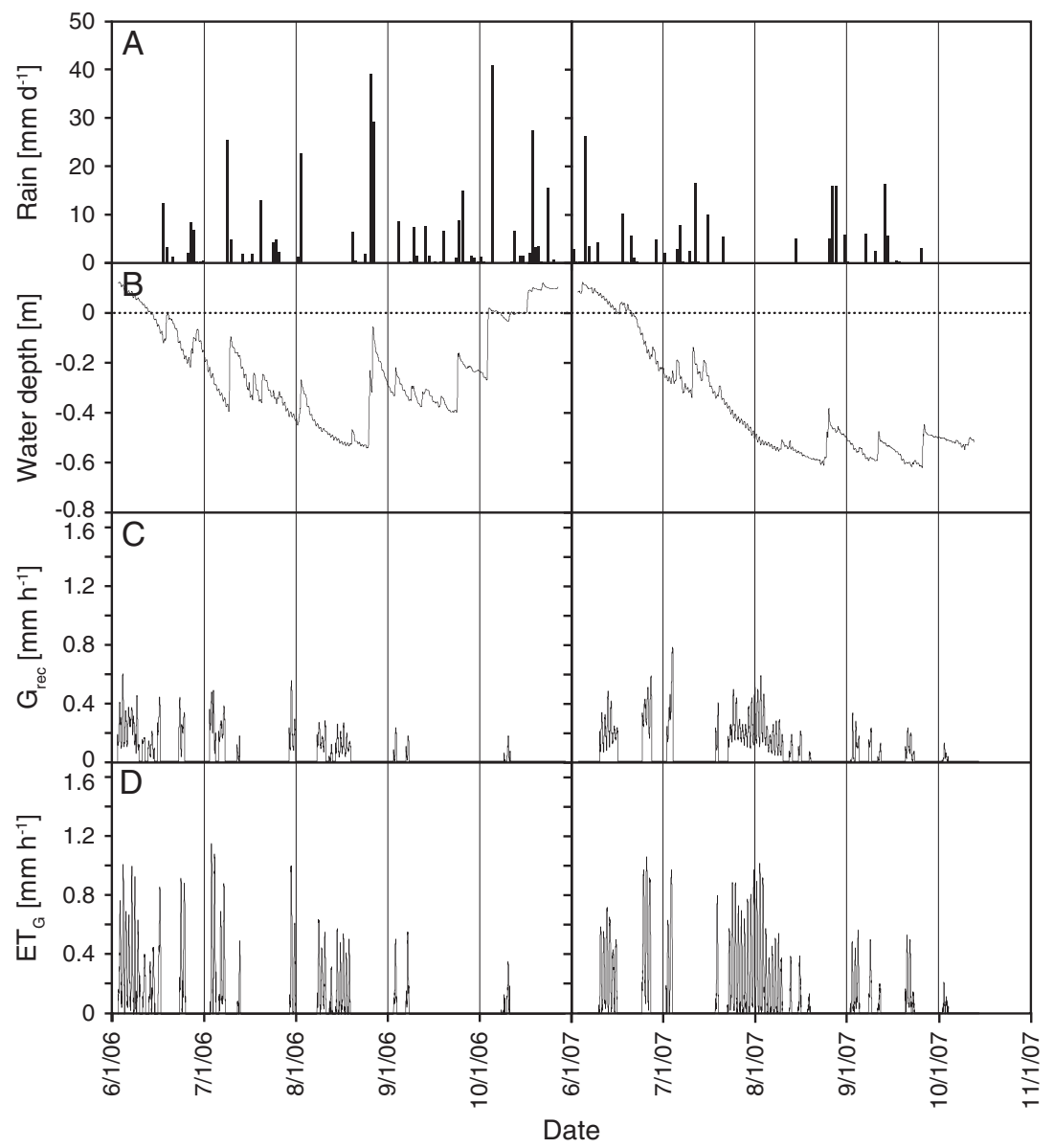

Figure 5. Precipitation (A), observed water depth (B), estimated shallow groundwater inflow $\left(G_{\mathrm{rec}}\right)(\mathrm{C})$ and estimated evapotranspiration $\left(\mathrm{ET}_{\mathrm{G}}\right)(\mathrm{D})$ for Swale 55, as an example, for the 2006 and 2007 growing seasons. The horizontal dotted line in B indicates zero water depth. Groundwater and ET were calculated using the methods presented in this study. Gaps in groundwater and ET records indicate days in which the method was not applicable (i.e. rainfall occurred or the slopes of the detrended water-table curves for sequential nights were not uniform).

September and October rain in 2006 resulted in water-level recovery to land surface, no such recovery occurred in 2007 prior to the end of the study.

Stage responses of the water table to precipitation varied depending on whether the water table was AGS or BGS. Precipitation events (Figure 5A) resulted in a rapid rise in BGS water levels but had a muted effect when standing water was present (Figure 5B). For example, the ratio of water-table rise to precipitation $\left(1 / S_{\mathrm{y}}\right)$ during flooded conditions in Swale 28 was 3.8 compared with 8.1 when the water table was below ground. The composite specific yield accounted for the differing response of the water table during flooded and non-flooded conditions. Considering the potential for a high degree of variability in ET that exists in wetland systems, ET $_{\mathrm{G}}$ corresponded favourably with $\mathrm{PET}_{\mathrm{PM}}$ when applied to AGS and BGS water levels simultaneously (Figures 6 and 7).

\section{Specific yield}

The composite specific yield methodology used to provide an estimate under flooded conditions compared well with observed specific yield values (Figure 8). The modelled trend matched the observed slope and slightly underestimated the intercept. At greater water depths, the specific yield of standing water $\left(S_{\mathrm{yw}}=1.0\right)$ was weighted higher than the specific yield of soil and sediment $\left(S_{\mathrm{ys}}\right)$, resulting in a greater composite specific yield $\left(S_{\mathrm{yc}}\right)$.

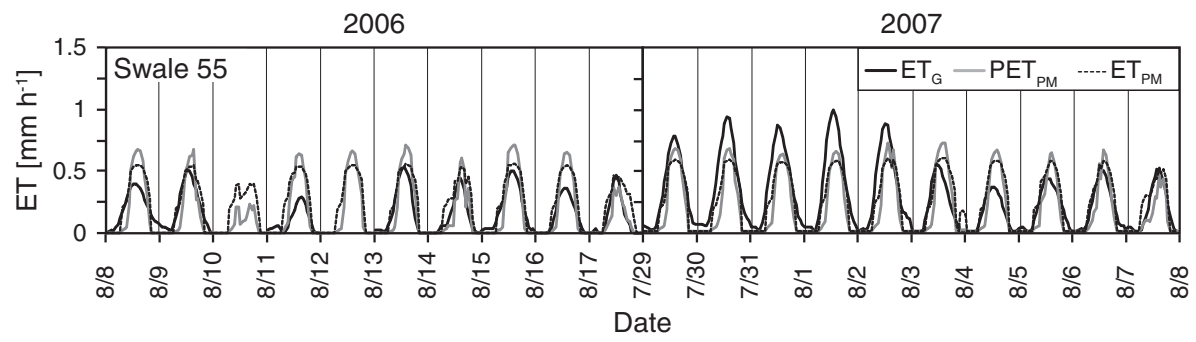

Figure 6. Comparison of estimated evapotranspiration $\left(\mathrm{ET}_{\mathrm{G}}\right)$, potential evapotranspiration calculated by the Penman-Monteith equation (PET $\left.\mathrm{PM}_{\mathrm{M}}\right)$ and the ET $\left(\mathrm{ET}_{\mathrm{PM}}\right)$ predicted by the power relationship between $\mathrm{PET}_{\mathrm{PM}}$ and $\mathrm{ET}_{\mathrm{G}}$ over two 10-day periods (8-18 July 2006 and 29 July to 8 August 2007$)$ at Swale 55, as an example. 


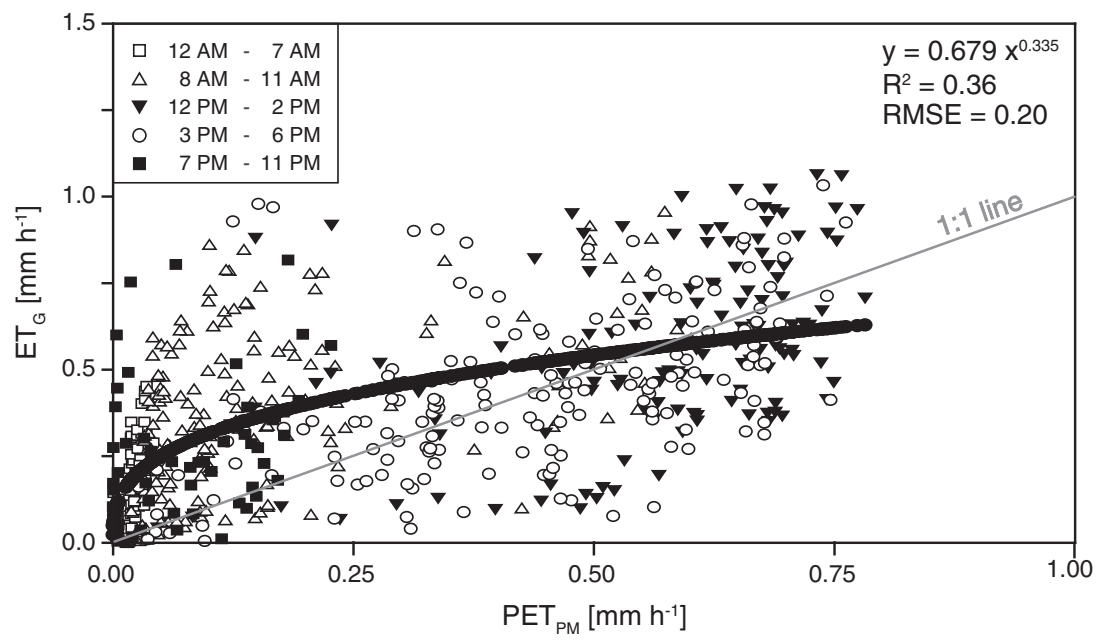

Figure 7. Estimated hourly ET $\left(\mathrm{ET}_{\mathrm{G}}\right)$ plotted against potential $\mathrm{ET}\left(\mathrm{PET}_{\mathrm{PM}}\right)$ at Swale 55 for the 2007 growing season, as an example. A power regression (equation in upper right) was used to relate $\mathrm{ET}_{\mathrm{G}}$ to $\mathrm{PET}_{\mathrm{PM}}$. The power regression line (bold black) is plotted, and the 1:1 line (thin gray) is shown for comparison. Points are plotted by symbol according to the time of day that they represent.

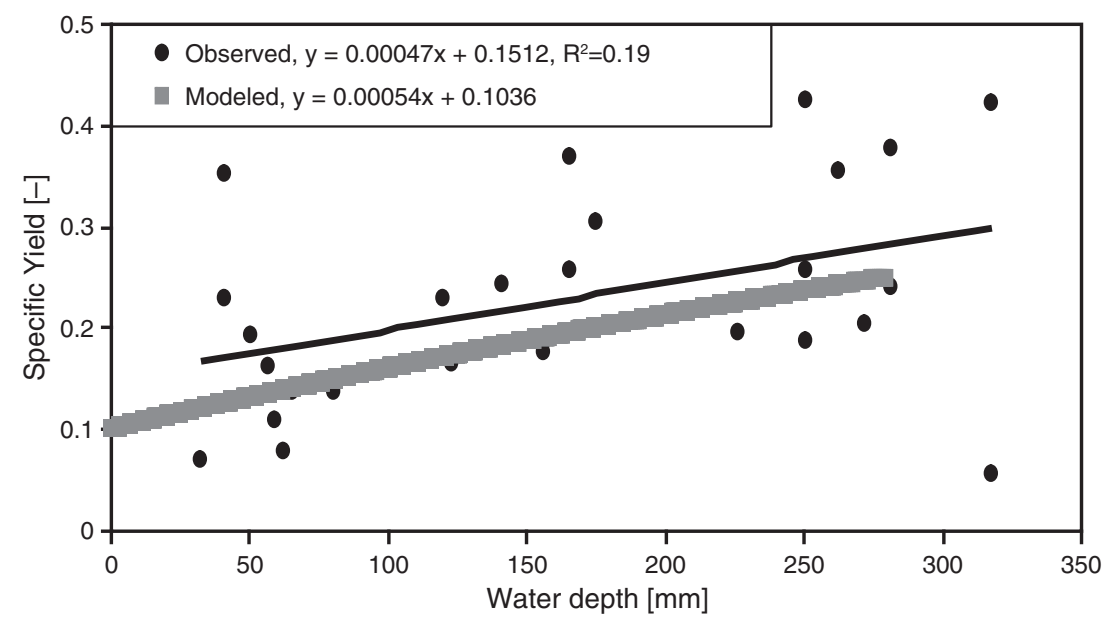

Figure 8. Plot of above-ground specific yield against water depth for the observed values (ratio of precipitation to water-table rise) and the values modelled using Equation (3) for Swale 28, as an example. At greater water depths, the specific yield of standing water $\left(S_{\mathrm{yw}}=1.0\right)$ is weighted higher in the equation than the specific yield of soil and sediment $\left(S_{\mathrm{ys}}\right)$, resulting in a greater composite specific yield $\left(S_{\mathrm{yc}}\right)$. The modelled relationship appears to be a relatively accurate description of the observed trend.

\section{Evapotranspiration}

Of the 131 days per year of the study, the WLF method was applicable to an average of 24 (standard deviation, $\mathrm{SD}=4.4$ ) days in 2006 and $40(\mathrm{SD}=4.9)$ days in 2007 , leading to a potentially more robust relationship between $\mathrm{ET}_{\mathrm{G}}$ and PET in 2007. ET $_{\mathrm{C}}$ hourly rates peaked near the end of July and beginning of August for most swales (e.g. Figure 5D). Comparable with previously published wetland ET values (Table II), the average daily rates over the 2006 growing season (June 3 to October 11) ranged from $4.0 \mathrm{mmd}^{-1}$ $(\mathrm{SD}=1.1)$ in Swale 8 to $6.6 \mathrm{~mm} \mathrm{~d}^{-1}(\mathrm{SD}=1.9)$ in Swale 73. The 2007 growing season showed average daily rates ranging from $4.1 \mathrm{~mm} \mathrm{~d}^{-1}(\mathrm{SD}=1.4)$ in Swale 26 to $6.5 \mathrm{~mm} \mathrm{~d}^{-1}$ $(\mathrm{SD}=1.5)$ in Swale 38. The highest mean daily rates generally were observed in July of 2006 and June of 2007.

Estimated ET values $\left(\mathrm{ET}_{\mathrm{G}}\right)$ approximated the $\mathrm{PET}_{\mathrm{PM}}$ calculations in magnitude (Figure 7), considering that a $1: 1$ relationship is not expected. Predicted ET values (e.g. ET $_{\mathrm{PM}}$ ) also showed good correspondence with empirically derived $\mathrm{ET}_{\mathrm{G}}$ (Figure 6). A power function was used because it minimized the RMSE $\left(\mathrm{mm} \mathrm{h}^{-1}\right)$ and described the data trend more realistically than a linear function (Figure 7).

When testing the potential effect of having a barometric pressure sensor above ground, and therefore subject to thermal effects, for the first month of the study (ordinal dates 154-183 in 2006), we found no significant difference between the monthly mean $\mathrm{ET}_{\mathrm{G}}$ values in June 2006 and June 2007 $\left(2006\right.$ mean $=-6.45 \mathrm{~mm} \mathrm{~d}^{-1} ; 2007$ mean $=-6.59$; ANOVA: $\left.F_{(1,28)}=0.13, p=0.72\right)$, suggesting that the thermal effects were minimal.

The two methods of estimating ET on days with rain included: (1) using our PET-ET ${ }_{\mathrm{G}}$ relationship and (2) assigning a zero ET value. Of the 133 days of our study in each year, rain was recorded on 48 days in 2006 and 43 days in 2007 . The majority of rain events were relatively short; events lasted for less than $4 \mathrm{~h}$ on $77 \%$ and $79 \%$ of those days in 2006 and 2007, respectively. On average, assigning a zero ET value on rainy days resulted in a significant $30 \%$ reduction in ET with respect to the PET-ET ${ }_{\mathrm{G}}$ relationship method (ANOVA; 2006: $F_{(1,28)}=66.8$, 
$\left.p<0.001 ; 2007: F_{(1,28)}=61.3, p<0.001\right)$. Whereas using the PET-ET ${ }_{\mathrm{G}}$ relationship, mean ET rates across all sites ranged from $3.97 \mathrm{~mm} \mathrm{~d}^{-1}$ to $6.15 \mathrm{~mm} \mathrm{~d}^{-1}$, using a zero ET assumption on rainy days resulted in ET estimates ranging from $2.73 \mathrm{~mm} \mathrm{~d}^{-1}$ to $4.39 \mathrm{~mm} \mathrm{~d}^{-1}$.

\section{Sources of water}

Mean daily $G_{\text {rec }}$ rates in 2006 ranged from $2.5 \mathrm{mmd}^{-1}$ $(\mathrm{SD}=1.2)$ in Swale 26 to $4.1 \mathrm{~mm} \mathrm{~d}^{-1}(\mathrm{SD}=1.5)$ in Swale 73 and from $2.6 \mathrm{~mm} \mathrm{~d}^{-1}(\mathrm{SD}=1.2)$ to $4.4 \mathrm{~mm} \mathrm{~d}^{-1}(\mathrm{SD}=2.2)$ for the same swales in 2007. Reversing head gradients in the groundwater system resulted in flow reversals at the edge of the swale over the course of the day. Loss by ET was followed by a gain in groundwater discharge, as evidenced by the lag in peak $\mathrm{ET}_{\mathrm{G}}$ and groundwater inflow $\left(G_{\text {rec }}\right)$ rates in Figure 4.

The linear regression used to predict groundwater $\left(G_{\mathrm{rec}}\right)$ from ET $\left(\mathrm{ET}_{\mathrm{G}}\right)$ performed well. Regressions for all swales were significant $(\alpha=0.05)$, and $R^{2}$ values ranged from 0.78 to 0.97 , with a mean of $0.91(\mathrm{SD}=0.04)$ across all swales in 2006 and 2007, suggesting that ET is a robust predictor of shallow groundwater flux at this site.

Shallow groundwater offset $59-73 \%$ of the water loss due to ET in 2006 and $59-75 \%$ in 2007, with the greater percentage offsets occurring when ET rates were low in the spring and fall (Figure 5). Precipitation accounted for 35-59\% of ET in 2006 but only $24-42 \%$ in 2007 . The sources of water calculated explicitly in the water budget (precipitation and groundwater inflow) were sufficient to account for loss due to ET, but water levels still declined over the growing season (Figure 5B), likely due to deep percolation loss (downward groundwater flux out of the rooting zone) following rainstorms.

\section{DISCUSSION}

The modifications used in this study to extend a sub-daily method applicable in semi-arid riparian wetlands (Loheide, 2008) to a general wetland scenario (e.g. flow-through wetlands in humid climates) afforded reasonable estimates of ET and groundwater-flow rates. Averaging $5.1 \mathrm{~mm} \mathrm{~d}^{-1}$ across all swales over the 2006 and 2007 growing seasons (June 3-October 11), mean daily ET was within the range previously reported at other wetland sites (Table II).

Calculation of PET has been utilized widely in wetland hydrologic studies because of the relatively simple weatherstation data requirements and continuous data record. Alternatively, WLFs can be useful for determining ET in that they reflect changes in plant life stage, community composition and antecedent moisture conditions, which PET does not (Lautz, 2008). Furthermore, WLF methods are not subject to variations in canopy structure, and estimates of groundwater-flow rates also can be extracted from the same analysis of WLFs (Gerla, 1992; Loheide et al., 2005; Butler et al., 2007; Hill and Neary, 2007; Gribovszki et al., 2008; Loheide, 2008). Application of WLF methods, however, has been limited thus far to riparian wetlands with subterranean water levels, with few exceptions (e.g. Hill and Neary, 2007). Despite the acknowledgment that WLF methods are 
underutilized in wetland applications (e.g. Butler et al., 2007), little improvement has been made to this end, perhaps because application to a general wetland scenario, to our knowledge, has never before been presented. Combining the two ET estimation methods is particularly useful for scaling PET estimates to WLF rates and estimating ET for days when WLF methods cannot be applied. Because ET varies greatly with atmospheric and soil conditions, combining the two methods affords a more realistic representation of AET rates than would averaging WLF values and applying the average to the entire growing season.

Previous application of WLF methods has occurred primarily in semi-arid riparian wetlands because inundation and rain events, both rare in such wetlands, pose an obstacle for using a WLF approach. The methodology presented here can be applied to a variety of wetland types in humid climates as well. The main requirements are that the wetland be connected to the groundwater system and that diurnal fluctuations in the water table are apparent in the hydrograph. As long as it can be assumed that the well in which water levels are measured is connected to the groundwater recovery source, this method is applicable. Complex surficial geologies that contain confining layers may disrupt this connection, and care should be taken to understand the hydrogeologic system when undertaking WLF studies. These techniques can be used in fens and other flow-through wetland systems but would not be appropriate for bogs and perched wetlands.

The method for calculating specific yield presented here allows for application to flooded conditions, thereby extending the utility of the WLF approach to a wider variety of wetlands with varying hydroperiods. Using this approach, we can use WLF methods for wetlands that experience periodic or sustained flooding, such as cattail marshes and wet meadows, in addition to forested and riparian wetlands. When water levels are below ground, the composite specific yield $\left(S_{\mathrm{yc}}\right)$ in Equation (3) becomes equivalent to the soil specific yield $\left(S_{\mathrm{ys}}\right)$, and a readily available specific yield (sensu Meyboom, 1967) can be used, thus maintaining the method's applicability in non-flooded conditions.

When applying this approach to humid climates, the rain dilemma - how to determine ET during prolonged precipitation events - becomes a particular challenge for ecohydrological studies involving plants. Understandably so, most studies omit calculations on such days altogether (e. g. Wilson et al., 2001; Mould et al., 2010). Available methods for calculating ET generate greater uncertainty on days when precipitation occurs. Micrometerological sensors (e.g. hygrometers, radiometers) tend to experience large errors when impacted by rain. Likewise, WLF methods are problematic because of the rain-induced rapid rise in watertable elevation and subsequent percolation loss that disconnects the measurement well from the groundwater recovery source. Assuming that no ET occurs on days with rain, however, is also empirically inaccurate, as diurnal losses are apparent in the hydrograph following rain events. Furthermore, plants tend to open their stomata under humid conditions and continue to photosynthesize and, therefore, transpire. In fact, as vapour pressure difference between ambient air and the leaf decreases, stomatal conductance increases (Avissar et al., 1985). Even so, optimal transpiration rates result from the right combination of soil water conditions, solar radiation, air temperature and water stress in addition to humidity (Lhomme, 2001). The overall effect of these conditions results in a decrease in ET rates on rainy days, primarily due to increased cloud cover and decreased temperatures. Because of these complicating factors, using a relationship between PET and $\mathrm{ET}_{\mathrm{G}}$ that combines information from two estimation techniques may provide a robust estimate, even on rainy days. When rain events last for a substantial portion of the day, as may be the case in subtropical and tropical climates, a zero ET assumption may be the best option. On the other hand, if a short rain event occurs, which was common in this study, the PET-ET relationship may be more appropriate. Therefore, it is important to take into account the manner in which climate affects precipitation frequency and duration at the site of interest, and choose the appropriate rainy day ET estimate accordingly.

In our study, the ET values derived by the PET-ET ${ }_{\mathrm{G}}$ relationship were $30 \%$ higher than estimates when zero ET was assumed for days with rain. Both methods produce results that are comparable with previously reported ET estimates (Table II). The resulting values of these approaches represent end members in the range of ET values; the former method may overestimate the AET, whereas the latter is an underestimate. Overall, our $\mathrm{ET}_{\mathrm{G}}$ corresponded favourably with calculated PET rates. $\mathrm{ET}_{\mathrm{G}}$ was sometimes greater and sometimes less than PET. Although we recognize that the amount of water transferred to the atmosphere by transpiration cannot exceed PET determined by atmospheric capacity for absorbing water vapour, both methods represent ET estimates and vary accordingly. Because WLF methods take into account additional factors regarding the plant community composition and canopy characteristics (Lautz, 2008), it is likely that AET is, indeed, higher when conditions allow than PET calculations would suggest. For example, on particularly sunny days when plants had ample water supply, we sometimes observed $\mathrm{ET}_{\mathrm{G}}$ values that were greater than PET (e.g. Figure 6; 7/29 to 8/2). The lack of exact congruency between $\mathrm{ET}_{\mathrm{G}}$ and PET is commonly encountered in such studies (e.g. Lott and Hunt, 2001; Andersen et al., 2005; Mould et al., 2010). Using the WLF and PET methods in conjunction can produce a more robust estimate that takes into account physical characteristics of the plant community and antecedent soil moisture as well as the micrometerologic conditions.

Daily estimates of ET are needed for water-budget analyses, water-resources management and climate-change predictions. Because groundwater inflow rates vary over the course of a day (Troxell, 1936; Gribovszki et al., 2008; Loheide, 2008), better estimates of ET can be obtained by WLF methods that calculate ET and groundwater inflow rates on a sub-daily, rather than daily, time step (Gribovszki et al., 2008; Loheide, 2008). If such a degree of accuracy is not required, however, the modifications presented here can be applied to the daily White (1932) method as well. Nonetheless, understanding how plants 
interact with hydrologic flow on a sub-daily basis may help water-resource managers predict the effects of groundwater withdrawal on riparian, coastal and other wetland ecosystems as well. A more thorough picture of water demands in wetland ecosystems across more climate zones also will enable water-resource and wetland managers to adapt to global climate change more effectively.

Uncertainty in the method is associated primarily with its sensitivity to specific yield $\left(S_{\mathrm{y}}\right)$, which is needed to adjust the ET and groundwater estimates from bulk aquifer volume to water volume (Meyboom, 1967; Nachabe, 2002; Loheide et al., 2005). For example, a $10 \%$ reduction in $S_{\mathrm{y}}$ would produce an average change in $\mathrm{ET}_{\mathrm{G}}$ of $1.66 \mathrm{~mm} \mathrm{~d}^{-1}$ over the growing season for Swale 28. Fortuitously, because the wells were developed in sand, classically defined $S_{\mathrm{y}}$ (saturation water content minus residual water content) closely approximates readily available $S_{\mathrm{y}}$ (water released over the period of a diurnal cycle) (Loheide et al., 2005). If this were not the case, readily available $S_{\mathrm{y}}$ dependent on sediment texture and water-table depth would need to be determined (Loheide et al., 2005).

Using the thickness of sediments $\left(D_{\mathrm{s}}\right)$ and water depth $\left(D_{\mathrm{w}}\right)$ to weight the soil and standing water components of specific yield provided a reasonable estimate for the composite specific yield when water levels were above ground, as shown in Figure 8. If anything, the method appears to underestimate $S_{\mathrm{y}}$ in that the modelled trend of the composite specific yield $\left(S_{\mathrm{yc}}\right)$ against water depth matches the slope but underestimates the intercept in comparison with the observed trend. The differences we observed between the AGS and BGS data sets were minimal, but errors may have been introduced when combining ET rate and groundwater-flux calculations for flooded and nonflooded conditions. For example, our assumption of a rectangular cross-sectional geometry with a much larger width than depth (Figure 2A) may have led to underestimation of ET. Because the water-level recorders were located on the lakeward side of each swale (position 1 in Figure 2), the portion of the water column representing standing water $\left(S_{\mathrm{yw}}=1.0\right)$ would be less than the bulk of the wetland if a more conic geometry was the case, as argued by Hill and Neary (2007) (Figure 2B). Other configurations (Figure 2C, Figure 2D), however, could lead to overestimation of $S_{\mathrm{yc}}$ and, therefore, ET. While some of the wetlands tended toward these geometries, ET rates for days when water levels were BGS were generally higher than for flooded conditions, suggesting that gross overestimation did not occur (Figure 5D).

Care must be taken to ensure that ET by this method is not estimated for several days following rain events until the water table has re-equilibrated with the recovery source. Fortunately, days when ET calculation may include percolation are readily evident from the hydrograph (Figure 5B) as an exaggerated decline in the water table following a rainstorm and are easily removed from the data set. Likewise, over-smoothing the water-level data leads to overestimation of ET and groundwater fluxes. Minimal smoothing should be applied. Finally, when a barometric pressure transducer is used, it must be placed in a dry well BGS so that it experiences similar temperatures as the submersed pressure transducer. Otherwise, gross overestimation of ET can occur (McLaughlin and Cohen, 2011; Cuevas et al., 2010). Although the barometric pressure transducer was in a well AGS for the first month of our study, the comparison of the resulting ET estimates to the subsequent year suggested that minimal overestimate occurred, likely because the temperature fluctuations at this northern latitude were not severe early in the year.

\section{CONCLUSIONS}

By extending the WLF method of estimating ET and shallow groundwater-flow rates to a general wetland scenario, we captured rates across two growing seasons in a highly variable Great Lakes coastal wetland system. Seasonally flooded conditions and periodic rain events meant that plants were rarely, if ever, water-limited and continued to transpire throughout the growing season. Deeper rooted trees on the ridges (e.g. birch, maple) also used groundwater and no doubt contributed to ET losses. More studies of diverse wetland types that span the growing season and take into account changes in plant water requirements are needed to capture the full range of ET losses. The generalized method presented here allows for calculation of ET and groundwater flow over a greater range of wetland conditions than previous adaptations of the WLF approach, thereby providing the opportunity for incorporating WLF methods over a wider array of ecohydrologic studies. Even in semi-arid riparian wetlands where WLF methods traditionally have been applied, this methodology may provide more accurate growing-season ET estimates. By providing a means for estimating two major components of the wetland water balance, this methodology could be adapted relatively easily by wetland resource managers operating under a wide range of climatic conditions.

\section{ACKNOWLEDGEMENTS}

Funding for this research was provided by the USGS Global Change Research Program and the University of Michigan School of Natural Resources and Environment and Rackham Graduate School. We thank Steve Baedke and Todd Thompson for providing data, thoughtful advice and assistance. We thank Deborah Goldberg and Donald Zak for their helpful contributions to this research. We thank field assistants Robert Mazur, Morgan Crutcher, Miriam Allersma, Erin Murphy, Amelia Letvin and Kelly Iknayan. We appreciate the help of Todd Rasmussen of the University of Georgia, who provided the code for performing regression deconvolution and insightful interpretation of unaccountable fluctuations in our data set. We appreciate comments by many reviewers, including Judy Drexler, Don Rosenberry, Zongfu Ge, Paul Seelbach and anonymous reviewers who helped to improve this 
manuscript. To our knowledge, no conflicts of interest exist that would affect this study.

This article is contribution 1721 of the USGS Great Lakes Science Center. Use of trade, product, or firm names is for descriptive purposes only and does not imply endorsement by the U.S. Government.

\section{REFERENCES}

Acreman MC, Harding RJ, Lloyd CR, McNeil DD. 2003. Evaporation characteristics of wetlands: experience from a wet grassland and a reedbed using eddy correlation measurements. Hydrology and Earth System Science 7: 11-22. DOI: 10.5194/hess-7-11-2003.

Allen RG, Prueger JH, Hill RW. 1992. Evapotranspiration from isolated stands of hydrophytes: cattail and bulrush. Transactions of the American Society of Agricultural Engineers 35: 1191-1198.

Allen RG, Pereira LS, Raes D, Smith M. 1998. Irrigation and Drainage Paper, No. 56. Crop Evapotranspiration-Guidelines for Computing Crop Water Requirements. Food and Agriculture Organization of the United Nations: Rome; 300

Allen RG, Walter IA, Elliott RL, Howell TA, Itenfisu D, Jensen ME, Snyder RL (eds). 2005. The ASCE Standardized Reference Evapotranspiration Equation. American Society of Civil Engineers: Reston; 70.

Allen RG, Pruitt WO, Wright JL, Howell TA, Ventura F, Snyder R, Itenfisu D, Steduto P, Berengena J, Yrisarry JB, Smith M, Pereira LS, Raes D, Perrier A, Alves I, Walter I, Elliott R. 2006. A recommendation on standardized surface resistance for hourly calculation of reference $\mathrm{ET}_{\mathrm{o}}$ by the FAO56 Penman-Monteith method. Agricultural Water Management 81: 1-22. DOI: 10.1016/j.agwat.2005.03.007.

Andersen HE, Hansen S, Jensen HE. 2005. Evapotranspiration from a riparian fen wetland. Nordic Hydrology 36: 121-135. DOI: 10.1016/j. jhydrol.2007.10.049.

Avissar R, Avissar P, Mahrer Y, Bravdo BA. 1985. A model to simulate response of plant stomata to environmental conditions. Agricultural and Forest Meteorology 34: 21-29. DOI: 10.1016/0168-1923(85)90051-6.

Boomer KMB, Bedford BL. 2008. Influence of nested groundwater systems on reduction-oxidation and alkalinity gradients with implications for plant nutrient availability in four New York fens. Journal of Hydrology 351: 107-125. DOI: 10.1016/j.jhydrol.2007.12.003.

Burkett VR, Wilcox DA, Stottlemeyer R, Barrow W, Fagre D, Baron J, Price J, Nielsen JL, Allen CD, Peterson D, Ruggerone G, Doyle T. 2005. Nonlinear dynamics in ecosystem response to climate change: case studies and policy implications. Ecological Complexity 2: 357-394. DOI: 10.1016/ j.ecocom.2005.04.010.

Butler JJ, Kluitenberg GJ, Whittemore DO, Loheide SP, Jin W, Billinger MA, Zhan X. 2007. A field investigation of phreatophyte-induced fluctuations in the water table. Water Resources Research 43: 1-12. DOI: $10.1029 / 2005$ WR004627.

Cleveland WS. 1979. Robust locally-weighted regression and smoothing scatterplots. Journal of the American Statistical Association 74: 829-836. DOI: $10.2307 / 2286407$.

Cleveland WS, Devlin SJ, Grosse E. 1988. Regression by local fitting: methods, properties, and computational algorithms. Journal of Econometrics 37: 87-114. DOI: 10.1016/0304-4076(88)90077-2.

Cuevas JG, Calvo M, Little C, Pino M, Dassori P. 2010. Are diurnal fluctuations in streamflow real? Journal of Hydrology and Hydromechanics 58: 149-162. DOI: 10.2478/v10098-010-0014-0.

Drexler JZ, Snyder RL, Spano D, Paw UKT. 2004. A review of models and micrometeorological methods used to estimate wetland evapotranspiration. Hydrological Processes 18: 2071-2101. DOI: 10.1002/ hyp. 1462.

Drexler JZ, Anderson FE, Snyder RL. 2008. Evapotranspiration rates and crop coefficients for a restored marsh in the Sacramento-San Joaquin Delta, California, USA. Hydrological Processes 22: 725-735. DOI: 10.1002/hyp.6650.

Ferris JG, Knowles DB, Brown RH, Stallman RW. 1962. Geological Water-Supply Paper 1536-E. Theory of Aquifer Tests. United States Government Printing Office: Washington; 174.

Gatewood JS, Robinson TW, Colby BR, Hem JD, Halpenny LC. 1950. U. S. Geological Survey Water Supply Paper 1103. Use of Water by Bottom-Land Vegetation in Lower Safford Valley Arizona. United States Government Printing Office: Washington; 210.

Gerla PJ. 1992. The relationship of water-table changes to the capillary fringe, evapotranspiration, and precipitation in intermittent wetlands. Wetlands 12: 91-98. DOI: 10.1007/BF03160590.
Gonthier GJ. 2007. Scientific Investigation Report 2007-5111. A Graphical Method for Estimation of Barometric Efficiency from Continuous Data: Concepts and Application to a Site in the Piedmont, Air Force Plant 6 , Marietta, Georgia. U.S. Geological Survey: Reston; 29.

Gribovszki Z, Kalicz P, Szilagyi J, Kucsara M. 2008. Riparian zone evapotranspiration estimation from diurnal groundwater level fluctuations. Journal of Hydrology 349: 6-17. DOI:10.1016/j. jhydrol.2007.10.049.

Hill AJ, Neary VS. 2007. Estimating evapotranspiration and seepage for a sinkhole wetland from diurnal surface-water cycles. Journal of the American Water Resources Association 43: 1373-1382. DOI: 10.1111/ j.1752-1688.2008.00167.x.

van der Kamp G, Hayashi M. 2009. Groundwater-wetland ecosystem interaction in the semiarid glaciated plains of North America. Hydrogeology Journal 17: 203-214. DOI: 10.1007/s10040-008-0367-1.

Laczniak RJ, DeMeo GA, Reiner SR, Smith JL, Nylund WE. 1999. WaterResources Investigation Report 99-4079. Estimates of groundwater discharge as determined from measurements of evapotranspiration, Ash Meadows area, Nye County, Nevada. U.S. Geological Survey: Reston; 70.

Lafleur PM, Hember RA, Admiral SW, Roulet NT. 2005. Annual and seasonal variability in evapotranspiration and water table at a shrubcovered bog in southern Ontario, Canada. Hydrological Processes 19: 3533-3550. DOI: 10.1002/hyp.5842.

Lautz L. 2008. Estimating groundwater evapotranspiration rates using diurnal water-table fluctuations in a semi-arid riparian zone. Hydrogeology Journal 16: 483-497. DOI: 10.1007/s10040-007-0239-0.

Lhomme J-P. 2001. Stomatal control of transpiration: examination of the Jarvis-type representation of canopy resistance in relation to humidity. Water Resources Research 37: 689-699. DOI: 10.1029/ 2000WR900324.

Loheide SP. 2008. A method for estimating subdaily evapotranspiration of shallow groundwater using diurnal water table fluctuations. Ecohydrology 1: 59-66. DOI: 10.1002/eco.7.

Loheide SP, Butler JJ, Gorelick SM. 2005. Estimation of groundwater consumption by phreatophytes using diurnal water table fluctuations: a saturated-unsaturated flow assessment. Water Resources Research 41: 1-14. DOI: 10.1029/2005WR003942.

Loheide SP, Deitchman RS, Cooper DJ, Wolf EC, Hammersmark CT, Lundquist JD. 2009. A framework for understanding the hydroecology of impacted wet meadows in the Sierra Nevada and Cascade Ranges, California, USA. Hydrogeology Journal 17: 229-246. DOI: 10.1007/ s10040-008-0380-4.

Lott RB, Hunt RJ. 2001. Estimating evapotranspiration in natural and constructed wetlands. Wetlands 21: 614-628. DOI: 10.1672/0277-212 (2001)021[0614:EEINAC]2.0.CO;2.

Mathworks. 2007. MATLAB R2007a, Version 7.4. Mathworks, Inc.: Natick.

McLaughlin DL, Cohen MJ. 2011. Thermal artifacts in measurements of fine-scale water level variation. Water Resources Research 47: W09601. DOI:10.1029/2010WR010288.

Meyboom P. 1967. Groundwater studies in the Assiniboine River drainage basin. Part II: hydrologic characteristics of phreatophytic vegetation in south-central Saskatchewan. Bulletin 139, Geological Survey of Canada; 62.

Mitsch WJ, Gosselink JG. 2000. Wetlands, 3rd edn, John Wiley \& Sons: New York; 920.

Monteith J. 1965. Evaporation and environment. In The State and Movement of Water in Living Organisms, 19th Symposium of the Society of Experimental Biologists, Fogg G (ed.) Cambridge University Press: Cambridge; 205-234.

Mould DJ, Frahm E, Salzmann T, Miegel K. 2010. Evaluating the use of diurnal groundwater fluctuations for estimating evapotranspiration in wetland environments: case studies in southeast England and northeast Germany. Ecohydrology 3: 294-305. DOI: 10.1002/eco.108.

Nachabe MH. 2002. Analytical expressions for transient specific yield and shallow water table drainage. Water Resources Research 38: 1193. DOI: 10.1029/2001WR001071.

Nagler PL, Morino K, Didan K, Erker J, Osterberg J, Hultine KR, Glenn EP. 2009. Wide-area estimates of saltcedar (Tamarix spp.) evapotranspiration on the lower Colorado River measured by heat balance and remote sensing methods. Ecohydrology 2: 18-33. DOI: 10.1002/eco.35.

National Oceanographic and Atmospheric Administration National Climate Data Center (NOAA). 2008. Annual Climatological Summary (Alpena County Regional Airport). Last accessed on October 10, 2008 at http:// www4.ncdc.noaa.gov/cgi-in/wwcgi.dll?wwDI StnSrch StnID 20010361.

Peel MC, Finlayson BL, McMahon TA. 2007. Updated world map of the Köppen-Geiger climate classification. Hydrology and Earth System Science 11: 1633-1644. DOI: 10.5194/hess-11-1633-2007. 
Penman HL. 1948. Natural evaporation from open water, bare soil and grass. Proceedings of the Royal Society of London 193: 120-145. DOI: $10.1098 /$ rspa.1948.0037.

Priban K, Ondok JP. 1985. Heat balance components and evapotranspiration from a sedge-grass marsh. Folia Geobotanica Phytotaxon 20: 41-56. DOI: $10.1007 / \mathrm{BF} 02856464$.

Rosenberry DO, Winter TC. 1997. Dynamics of water-table fluctuations in an upland between two prairie-pothole wetlands in North Dakota. Journal of Hydrology 191: 266-289. DOI: 10.1016/S0022-1694(96) 03050-8.

Sanderson JS, Cooper DJ. 2008. Ground water discharge by evapotranspiration in wetlands of an arid intermountain basin. Journal of Hydrology 351: 344-359. DOI: $10.1016 / \mathrm{j}$. jhydrol.2007.12.023.

Schilling KE. 2007. Water table fluctuations under three riparian land covers, Iowa (USA). Hydrological Processes 21: 2415-2424. DOI: 10.1002/ hyp.6393.

Schilling KE, Kiniry JR. 2007. Estimation of evapotranspiration by reed canarygrass using field observations and model simulations. Journal of Hydrology 337: 356-363. DOI: 10.1016/j.jhydrol.2007.02.003.

Seber GAF, Wild CJ. 2003. Nonlinear Regression. Wiley-Interscience: Hoboken; 768.

Shuttleworth WJ. 1993. Evaporation. In Handbook of Hydrology, Maidment DR (ed.) McGraw-Hill Inc.: New York; 4.1-4.53.

Snyder FF. 1938. Synthetic unit-graphs. Transactions of the American Geophysics Union 19: 447-454.

Souch C, Wolfe CP, Grimmond CSB. 1996. Wetland evaporation and energy partitioning: Indiana Dunes National Lakeshore. Journal of Hydrology 184: 189-208. DOI: 10.1016/0022-1694(95)02989-3.
Souch C, Grimmond CSB, Wolfe CP. 1998. Evapotranspiration rates from wetlands with different disturbance histories: Indiana Dunes National Lakeshore. Wetlands 18: 216-229. DOI: 10.1007/BF03161657.

Sun L, Song C. 2008. Evapotranspiration from a freshwater marsh in the Sanjiang Plain, Northeast China. Journal of Hydrology 352: 202-210. DOI: 10.1016/j.jhydrol.2008.01.010

Troxell HC. 1936. The diurnal fluctuation in the groundwater and flow of the Santa Ana River and its meaning. EOS Transactions, American Geophysical Union 17: 496-505.

USDA, NRCS. 2008. Web Soil Survey. Last accessed on February 2, 2008 at http://websoilsurvey.nrcs.usda.gov/app/WebSoilSurvey.aspx.

USDA, NRCS. 2011. The PLANTS Database. National Plant Data Team, Greensboro, NC 27401-4901 USA. Last accessed on August 30, 2011 at http://plants.usda.gov, 30 August 2011.

Wessel DA, Rouse WR. 1994. Modelling evaporation from a wetland tundra. Boundary-Layer Meteorology 68: 109-130. DOI: 10.1007/ BF00712666.

White WN. 1932. Water-Supply Paper 659-A. A Method of Estimating Groundwater Supplies Based on Discharge by Plants and Evaporation from Soil. U.S. Geological Survey: Washington; 105.

Williams DG, Scott RL, Huxman TE, Goodrich DC, Lin G. 2006. Sensitivity of riparian ecosystems in arid and semiarid environments to moisture pulses. Hydrological Processes 20: 3191-3205. DOI: 10.1002/hyp.6327.

Wilson KB, Hanson PJ, Mulholland PJ, Baldocchic DD, Wullschleger SD. 2001. A comparison of methods for determining forest evapotranspiration and its components: sap-flow, soil water budget, eddy covariance and catchment water balance. Agricultural and Forest Meteorology 106: 153-168. DOI: 10.1016/S0168-1923(00)00199-4. 